\title{
Designing Of Aerobic Gymnastics Campaign To Reduce The Risk Of Dementia In The Early Adulthood
}

\author{
Diana Fajar Rahmawati ${ }^{1}$, Sonson Nurusholih ${ }^{2}$ \\ ${ }^{1}$ Telkom Creative Industries School, Telkom University, Bandung, Indonesia \\ ${ }^{2}$ Telkom Creative Industries School, Telkom University, Bandung, Indonesia \\ dianarahw@gmail.com (Diana Fajar Rahmawati), artson_mail@yahoo.com (Sonson Nurusholih)
}

\begin{abstract}
The prevalence of dementia sufferers is directly proportional to life expectancy. The higher life expectancy, then the likelihood of dementia are also high. In the city of Bandung, life expectancy exceeds the National life expectancy, so that estimated an increased amount of dementia can occur a few years to come. If in general dementia occurs at around the age of 60 years, yet a study mentions that the early adulthood can also be exposed to disease or dementia, called with the phenomenon of 'Pikun Usia Dini' indicated as early symptoms of dementia or early onset dementia (Young Onset Dementia). The lifestyle is one of the risk factors of the occurrence of dementia at an early age. Aerobic gymnastics regularly can reduce the risk of the development of the onset of dementia. Aerobic gymnastics can stimulate the cells of neurons in the brain become active. At the beginning of adulthood with normal body fitness level, can do mix impact aerobics. Method study of the literature, observation, interview, questionnaire and analysis matrix, and communication strategy The Facets Model of Effects used to convey information about the solutions reduce the risk of dementia through aerobic gymnastics and the determination of the medium used. The form of media event, ambient, posters, videos and other supporting media. The benefits of this campaign was to inform the dangers of dementia and aerobic gymnastics as a prevention efforts through a series of campaign strategies.
\end{abstract}

\section{Keywords Dementia, Aerobics, Campaign.}

\section{Introduction}

The life expectancy exert powerful enough in the rising age of life expectancy, and are associated with an increased prevalence of chronic diseases, such as dementia. According to the 2010 census data, the number of aged 60 and above the Bandung city reached 6.6 percent. This can happen because, one, influenced by the increasing age of life expectancy in the city of Bandung which had already reached 73.4 years. Whereas the national life expectancy of age only reached 70.7 years (SurveyMETER and CAS UI, 2013). In this case it can be predicted that the Bandung city also experienced an increase in the prevalence of dementia in the next few years.

Dementia itself is a medical term for a disease of progressive mental condition in the form of a decline in cognitive function in a person. In the dementia occurs a decrease in memory that goes slowly but gradually got worse. This disease can interfere with daily activities, for example, forget how to eat, drive, connect social, even forget the way home. In General dementia strikes someone around the age of 60 , but research conducted by Tantowi, etc (2013) refer to this phenomenon as 'Pikun Usia Dini' and indicated as early symptoms of dementia or early onset dementia (Young Onset Dementia). Experienced dementia at a younger age when the predispotition factor obtained due to the earlier pattern of life, like lazy doing some sport activity. The measures have been done of Bandung was founded the organization called ALZI Bandung. The organization aims to help improve the quality of life of people with dementia (ODD) (Alzheimer's Indonesia, 2013). But until now, there hasn't been a campaign reduces the risk of dementia that is devoted to the early adulthood as a preventive action to reduce the risks. According to Dr. Yustiani Dikot, Sp.S. (2016) the way of them exercise stimulates the brain with filling activities to train the body to keep moving despite only with a short duration, and perform social activities which may reduce depression. Some studies report that someone who does physical activity in the form of aerobic gymnastics exercises experienced a decrease in symptoms of dementia and cognitive function improvement which can improve memory (Yaffe et al, 2001). By doing aerobic gymnastics on a regular basis will also stimulate cells of neurons in the brain become active. Reduce the risk of dementia can also help the Government carry out its program for the city of the friendly Elderly in Bandung. Therefore the design of this campaign are considered very important as a preventive action to reduce the risk of dementia. The efforts of the drafting changes made by the campaignrelated knowledge, attitudes, and behaviors. The hope of the existence of this campaign is to generate campaigns that are 
informative, communicative, and persuasive in accordance with theory.

\section{Theoritical Background}

\subsection{Methods}

The campaign is the activity of the complex interrelated and coordinated through a design to enhance the awareness of the target audience in particular (Moriarty, dkk, 2011). According to Clow and Baack (2007), the campaign is the process of preparing and integrating specific advertising program in conjunction with the message as a whole. Of the understanding it can be concluded that the campaign is the activity of designing processes to communicate and convey information to a wider audience with a specific target audience which is done at a specific time.

Communication is an interaction use code isarat or good visually, verbal or other languages such as attitudes, gestures and other forms. (Anthony, 2006:35-37). According to Dennis 1. Wilcox communication is the process of sending information, ideas, and attitudes of individuals to other individuals. In the communication process consists of what is called with the communicator or the giver and receiver of the message, or the message recipients (2003:170). The second of the above theories can be summed up that communication is an activity of the interaction with the intention of giving the message and change the attitudes of the recipient of the message.

Effective communication occurs when a message is delivered to the target of concern, provide information, and sometimes can also be entertaining. The Facets Model of Effects is a new model approach to evaluate the effectiveness of the workings of advertising. Mentioned that advertising is effective will create six aspects of consumer response. (Moriarty, dkk, 2011). Six aspects of The Facets Model of Effects is as follows:

a. Perceive (Perception) Perception is a process so that the audience can accept the message conveyed through our senses senggga can be effective. Target audience very selective to pay attention to what they want to watch. So, advertisers often bombarding target audience with words and information online (e.g. social media) to get the attention of your target audience. To maximize the attraction of target audience, usually advertisers don't want their ads just read and left well enough alone, but advertisers also want target audience curiosity with tempting their senses, for example by presenting words or visual that has never seen or heard before by target audience.

b. Understand (Cognition) Facts, information and description leads to an understanding of the target audiences. In this aspect, advertisers want a sasaeran audience to discover the truth, the relevance and urgency of a content. How consumers are thinking of looking for a information or respond to information, how to learn and understand something so that it can make a rational response against the message.

c. Feel (Affective/Emotion) this aspect is about how advertisers create a sense of the emotions (desire) of the target audience. Emotion is a great way to feel the most effective response to reflect about feeling something, so as to stimulate desire and emotions so that it creates a sense of love and gives rise to feeling. When creating content on this aspect, which should be thought through is how the content is to make an emotional impact towards the target audience. d. Connect (Association) A communication technique that is one of the symbols to create relationships between communication with the campaign undertaken to draw attention to the target audience through social media. This occurs when the mind and feelings of the audiences became associated with the content being advertised through the repetition of the message. Target audience are easily connected through messages in the content are made.

e. Believe (Persuasion) Target audience can only be persuaded to act when they believe the message of the advertiser content. This aspect is a way of communication to raise awareness of a party in order to influence and motivate others that they believe in and want to do something so that it can create confidence. When the target audience interacting, they will help persuade each other and form an opinion of one another. Finally, create content advertisers more trustworthy and credible loyalty that leads to the target audience.

f. Act (Behavior) There are many ways that you can use in this aspect because the understanding of how the target audience acts translated into what can be done by advertisers to help shape the behavior of the target audience. One of the ways the simplest but most effective is a call to action. Provide direct action and show the interaction with the target audience so that it can represent a direct response. Test products are also often used by advertisers because the target audience can start to form a habit with samples of products or services. The more target audience experience of content created by advertisers and see how it has benefits against their lives, then the possibility of changing the behaviour of the target audience are also getting bigger.

\subsection{Data Used}

Data collecting techniques include:

1. Observation field

2. Study of literature

3. Interviews

4. Questionnaire

\subsection{Instrumentations}

a. Demographics

gender: men and women

main Target: the 18-24 years (Early Adulthood)

secondary Target: the 25-40 years (adults)

the economic and Social Status: C, B, A (a middle-class, upper middle, and top) author of Considerations in choosing a target audience is based on observations that showed that at age 18 to 24 years old (Early Adulthood) the majority of the students actively join the Alzheimer's Foundation is affiliated to Indonesia so that expected to invite its environment for care in dementia and participate in this campaign. As well as prevention efforts are exposed to the risk of dementia for the age to come. While at the age of 2540 years (adult) is a masayarakat that has a job and a steady income with social and economic Status (SES) middle 
class to upper class which is very prone to developing the disease is not contagious.

\section{b. Geographically}

Located in Bandung, because the city has a high life expectancy which is predicted is directly proportional to the prevalence of dementia a few years to come. In addition to supporting the Government program as a town of friendly elderly.

c. Psychographic a) Care about health b) active c) likes to socialize and perform social activities. d) love music, love to come to the event.

\section{Results and Discussion}

The campaign will be communicated by using the dayaotarik message through emotional approach to the style of pieces of everyday life or a slice of life that is hyperbole in order to target audience as if experiencing directly the message conveyed in this campaign. While the language to be used in the campaign adopted a style of speech that is used everyday for the target audience's emotional touches the target audience, but still are telling. The style of language used in this campaign is the stylistic ironies, that subtle satire.

\subsection{Message Strategy}

The message will be conveyed to the target audience in this campaign of matrix analysis results on previous campaigns. The approach used to deliver the message of the campaign on a target audience is emotional and rational approach. Message: Fun Aerobics is a brain booster

This message conveys the Strategy directly that aerobic gymnastics is a great solution to reduce dementia because it can provide an impact is good for brain health. Based on an analysis of previous data, the age of the target audience to prefer things that are not boring, then the word "Aerobics" juxtaposed with the word "Fun" ' aims to change the mind of the target audience about the aerobic gymnastics impressed old-fashioned. Whereas, for the name of the logo is Fit Aerobics. The word "Fit" means fit or healthy. "Fit" here devoted to brain health. The tagline of the campaign as well as listed in the Aerobic Fun logos are Cerebrum Nyentrik. The meaning of the word "nyentrik" is a stylish eccentric, that is something that looks gaudy or obtrusive. This tagline can facilitate target audience to understand the message of the campaign. In addition to the message and the tagline, the campaign is also using the tagar \#ButuhAerobik. In General, the use of tagar was intended to classify a particular content on social media, so the content containing the tagar easily traced. Tagar allows audiences to find infrmasi about this campaign in social media. In the event, event name or headline used was the Nyentrik Aerobics has meaning with the tagline that was used.

\subsection{Media Strategy}

According to Safanayong (2011), the proper media is that correspond with the objectives, communication, and budget. If effective media to deliver the message and be accepted exactly as well as be able to invite the target audience to change their attitude.

a. Main Media Main media selected for this campaign is the event. This consideration of the purpose of the campaign that is in addition to providing the information also invited target audience to change their attitude, so it takes a real participation of the target audience in the following campaign. Following the event, the target audience will get the answer from this campaign strategies. So, is expected to be a similar desire to act after the event from taking place. Later in the event will also be given information on the early dementia through talkshow with experts as an influencer to arouse the awareness of the target audience.

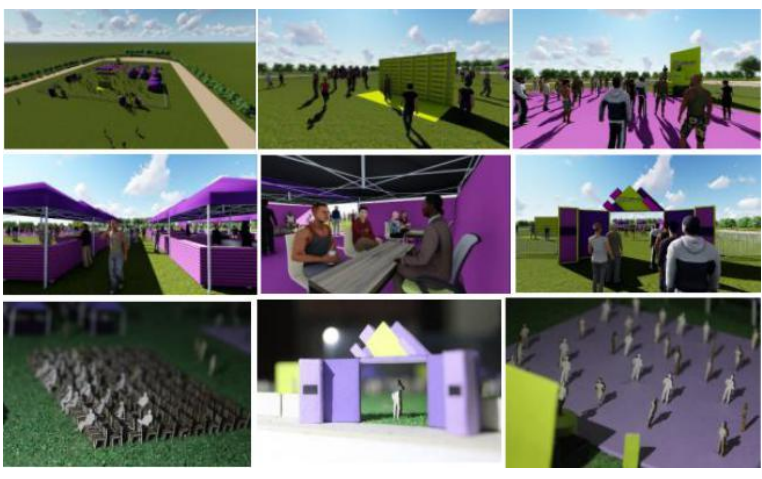

Picture 3.1 Event as Main Media

Source: Diana Fajar, 2017

b. Supporting Media Used to support the mainstream media. This supporting media, raised awareness of the initial target audience was followed by teaser event information. Supporting media to be used in this campaign include: 1. Ambient Ads 2. Poster 3. Video Teaser 4. Website 5. Social Media 6. Merchandise

\begin{tabular}{|l|l|l|}
\hline The purpose of the communication & Responss & Media \\
\hline Perception & See/Hear & Ambient, Poster Teaser, Video Teaser \\
\hline Affective/Emotion & Feel & Ambient, Poster Teaser \\
\hline Cognition & Understanding & Website, Instagram/Social \\
\hline Association & Connected & Social Media Post, Challenge, Logo, Influencer \\
\hline Persuasion & Believe & Print Ad, Sosial Media Post \\
\hline Behavior & Act & Event, Merchandise \\
\hline
\end{tabular}

Table 3.1 Facet Model of Effects

Source: Diana Fajar, 2017

This campaign will be carried out for three months. The application of media adapted to the six aspects of The Facet Model of Effects. Following the application of media based on time schedule: 


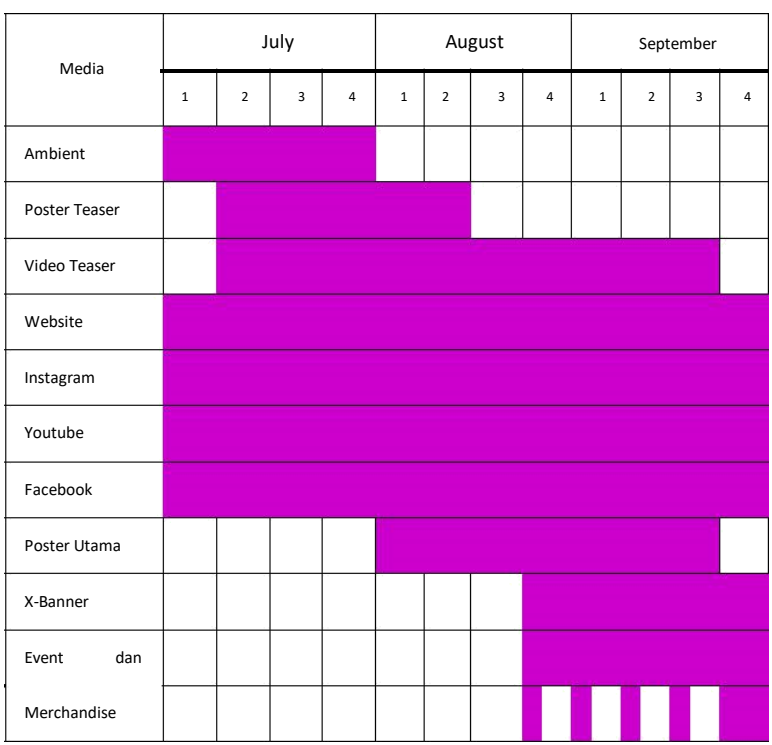

Tabel 4.2 Time Schedule

Source: Diana Fajar, 2017

\section{Conclusion}

Dementia hasn't been a concern of the community of Bandung city. This is due to dementia is considered a normal process that occurs in older people. Whereas, dementia can attack the early adult age because it is a progressive disease. Until now, dementia has yet to be healed, but the risk may be reduced. To reduce the risk then the author felt the need to do a campaign about prevention of acts that can be done as a community information and education through the media campaign "Aerobic Nyentrik" devoted to the early adulthood, due to early onset dementia early average appeared on this age.

\section{ACKNOWLEDGEMENT(S)}

This research was supported/partially supported by Alzheimer's Indonesia. I thank my colleagues from Telkom University who provided insight and expertise that greatly assisted the research, although they may not agree with all of the interpretations/conclusions of this paper.

\section{REFERENCES}

[1] Hartati, Sri, dan Costrie Ganes Widayanti. "CLOCK DRAWING: ASESMEN UNTUK DEMENSIA (Studi Deskriptif pada Orang Lanjut Usia Di Kota Semarang)." Jurnal Psikologi Undip 7.1 (2010): 1-10.

[2] Martin Prince, Anders Wimo, etc. "World Alzheimer Report 2015: The Global Impact of Dementia: an Analysis of Prevalence, Incidence, Cost and Trends". Published by Alzheimer's Disease International (ADI), London. August 2015.

[3] Rogers, E. M., \& Storey J. D. (1987). Communication Campaign. Dalam C. R. Berger \& S.H. Chaffe (Eds.), Handbook of Communication Science. New Burry Park, CA:Sage
[4] Sugiyono. 2009. Memahami Penelitian Kualitatif: Dilengkapi Contoh Proposal dan Laporan Penelitian. Bandung:Alfabeta.

[5] Tamher, S. "Kesehatan usia lanjut dengan pendekatan asuhan keperawatan." Jakarta: Salemba Medika (2009). Wiseman, Richard. 2012. Lupakan Berfikir Positif, Saatnya Bertindak Positif. Jakarta:Gemilang.

[6] Moriarty, Sandra \& Nancy Mitchells, William Wells. 2007. Principles and Effective IMC Practice. Singapore : Prentice Hall

[7] Moriarty, Sandra \& Nancy Mitchells, William Wells. 2011. Advertising : 8th edition. Jakarta:Kencana

[8] Jefferies, K and Agrawal, N. 2009. Early-Onset Dementia. Journal of Continuing.

[9] Kuntjoro, ZS. 2002. Pengenalan Dini Demensia (Predemensia). Diambil dari: www.e-psikologi.com/usia/170602.htm.

[10] Professional Development. 15: 380-388.Kenneth E. Clow, Donald Baack. 2007. Integrated Advertising, Promotion, and Marketing Communications. New Jersey: Pearson Prentice Hall.

[11] Cheng, Hong., Kotler, Philip., \& Lee, Nancy R. (2011). Social Marketing for Public Helath Global Trends and Success Story. Massachusetts: Jones and Bartlett Publishers. 